\author{
Н. Д. Дячук \\ orcid.org/0000-0002-5853-253X \\ викладач кафедри господарського права \\ юридичного факультету \\ Ужгородського національного університету
}

\title{
НАЦІОНАЛЬНА ІНСТИТУЦЙНА СИСТЕМА АДМІНІСТРАТИВНО-ПРАВОВОГО РЕГУЛЮВАННЯ ЗАХИСТУ УКРАЇНСЬКИХ КАРПАТ
}

Постановка проблеми. У процесі розвитку України як демократичної і правової держави, євроінтеграції України, захисту довкілля, забезпечення сталого лісокористування та водокористування, збереження екосистеми Українських Карпат вагомого значення набуває дослідження проблематики національної інституційної системи адміністративно-правового регулювання захисту Українських Карпат.

Дослідження національної інституційної системи адміністративно-правового регулювання захисту Українських Карпат має вагоме практичне значення для подальшого розвитку законодавства України про захист Українських Карпат, про забезпечення сталого господарювання в лісах України, про водні ресурси, про тваринний та рослинний світ, а також для покращення практичної діяльності вповноважених суб’єктів у відповідній сфері. 3 огляду на це, дослідження проблематики національної інституційної системи адміністративно-правового регулювання захисту Українських Карпат є важливим для розвитку сучасної науки адміністративного права.

Мета статті - охарактеризувати проблематику національної інституційної системи адміністративно-правового регулювання захисту Українських Карпат.

Завдання статті - сформулювати авторське визначення поняття «національна інституційна система адміністративно-правового регулювання захисту Українських Карпат», визначити окремі елементи національної інституційної системи адміністративно-правового регулювання захисту Українських Карпат.

Стан дослідження. Проблематика національної інституційної системи адміністративно-правового регулювання захисту Українських Карпат є актуальною, а окремі їі аспекти були предметом дослідження багатьох сучасних науковців: Л. Брославського, Т. Коломоєць, Я. Лазура, О. Микитюка та Н. Хлуденєвої.

Виклад основного матеріалу. Національна інституційна система адміністративно-правового регулювання захисту Українських Карпат є невід’ємним складником єдиної цілісної інституційної системи адміністративно-правового регулювання захисту Українських Карпат.
Національна інституційна система адміністративно-правового регулювання захисту Українських Карпат - це система вповноважених суб'єктів, які діють на основі внутрішньодержавного права України і які здійснюють адміністративно-правове забезпечення захисту Українських Карпат.

До національної інституційної системи адміністративно-правового регулювання захисту Українських Карпат належать такі вповноважені суб'єкти:

1) Верховна Рада України, яка, зокрема, ухвалює закони з питань забезпечення захисту Українських Карпат: «Про оцінку впливу на довкілля» [1] від 23 травня 2017 року, «Про заборону на проведення суцільних рубок у гірських ялицево-букових лісах Карпатського регіону» [2] в редакції від 30 жовтня 2019 р. та ін., а також ратифікує відповідні міжнародні договори України;

2) Президент України. Вагоме значення для розбудови ефективної системи адміністративно-правового регулювання захисту Українських Карпат мають укази Президента України у сфері довкілля: Указ Президента України «Про Положення про Державну екологічну інспекцію України» [3] від 13.04.2011 № 454/2011, розпорядження Президента України «Про делегацію України для участі у 10-й Конференції Сторін Віденської конвенції про охорону озонового шару та 26-й Нараді Сторін Монреальського протоколу про речовини, що руйнують озоновий шар» [4] від 14 листопада 2014 року № 1242/2014-рп;

3) Кабінет Міністрів України, міністерства, інші центральні органи виконавчої влади, які мають низку повноважень щодо забезпечення регулювання захисту Українських Карпат;

4) Уповноважений Верховної Ради України 3 прав людини (омбудсмен). Так, результати парламентського контролю Уповноваженого з прав людини за дотриманням гарантованих ст. 50 Конституції України [5] прав людини на безпечне для життя і здоров'я довкілля, вільний доступ до інформації про стан довкілля засвідчили, що у 2013 р. центральними та місцевими органами влади вживалися певні заходи на внесені Омбудсманом акти реагування щодо забезпечення екологічних прав людини шляхом як норматив- 
но-правого врегулювання проблем екологічної безпеки людини, так і застосування інших адміністративних повноважень для їх поновлення;

5) суди України, зокрема й Конституційний Суд України, які можуть ухвалювати відповідні рішення у сфері забезпечення захисту Українських Карпат.

Суди в Україні діють на основі Конституції України, Закону України «Про судоустрій і статус суддів»[6] від 07 липня 2010 року, інших законів України.

Рішення судів України у справах щодо забезпечення регулювання захисту Українських Карпат є суперечливими і неоднозначними, як-от у справі щодо побудови вітроелектростанції на полонині Боржави. Так, 24 січня 2020 року Закарпатський окружний адміністративний суд відмовив у задоволенні позову Громадської організації «Міжнародний інститут людини і глобалістики «Ноосфера» до Державної архітектурно-будівельної інспекції України (третьою особою, яка не висуває самостійних вимог щодо предмета спору, є Товариство з обмеженою відповідальністю «Атлас Воловець Енерджи») про визнання протиправними дій та анулювання дозволу [7], не дивлячись на активний спротив громадськості та численні порушення законодавства в процесі оформлення та видання відповідних документів.

Вагому роль у процесі забезпечення прав і свобод громадян у сфері забезпечення захисту Українських Карпат відіграє Конституційний Суд України. Він провадить свою діяльність на основі Конституції України і Закону України «Про Конституційний Суд України»[8] від 16 жовтня 1996 року;

6) Прокуратура України, яка здійснює практичну діяльність щодо належного забезпечення захисту Українських Карпат;

7) центральні та місцеві органи виконавчої влади, серед яких провідну роль відіграє Міністерство захисту довкілля та природних ресурсів України, положення про яке затверджене постановою Кабінету Міністрів України «Про затвердження Положення про Міністерство захисту довкілля та природних ресурсів України» [9] від 25 червня 2020 р. № 614;

8) органи місцевого самоврядування: сільські, селищні та міські ради, районні та обласні ради. Органи місцевого самоврядування України діють на основі Закону України «Про місцеве самоврядування в Україні» [10] від 21 травня 1997 року, а службовці органів місцевого самоврядування діють на основі Закону України «Про службу в органах місцевого самоврядування» [11] від 7 червня 2001 року.

Згідно зі ст. 33 Закону України «Про місцеве самоврядування в Україні» до відання виконавчих органів сільських, селищних, міських рад належать такі повноваження:
- підготовка і внесення на розгляд ради пропозицій щодо встановлення ставки земельного податку, розмірів плати за користування природними ресурсами, вилучення (викупу), а також надання під забудову та для інших потреб земель, що перебувають у власності територіальних громад; визначення в установленому порядку розмірів відшкодувань підприємствами, установами та організаціями незалежно від форм власності за забруднення довкілля та інші екологічні збитки;

- підготовка і подання на затвердження ради проектів місцевих програм охорони довкілля, участь у підготовці загальнодержавних і регіональних програм охорони довкілля;

- підготовка і внесення на розгляд ради пропозицій щодо прийняття рішень про організацію територій і об'єктів природно-заповідного фонду місцевого значення та інших територій, що підлягають особливій охороні; внесення пропозицій до відповідних державних органів про оголошення природних та інших об’єктів, що мають екологічну, історичну, культурну або наукову цінність, пам'ятками природи, історії або культури, які охороняються законом;

9) адвокатура. Адвокати та їх об’єднання можуть надавати правову допомогу щодо забезпечення права громадян на вільний доступ до інформації про стан довкілля, а також інші види правової допомоги клієнтам із метою належного забезпечення захисту Українських Карпат;

10) засоби масової інформації (далі 3MI), зокрема й електронні ресурси: вебсайти, тематичні групи та сторінки у соціальних мережах та месенджерах.

3МІ в Україні діють на основі: Закону України «Про інформацію» від 2 жовтня 1992 року, Закону України «Про друковані засоби масової інформації (пресу) в Україні» [12] від 16 листопада 1992 року, Закону України «Про телекомунікації» [13] від 18 листопада 2003 року, Закону України «Про основні засади розвитку інформаційного суспільства в Україні на 2007-2015 рр.» [14] від 09 січня 2007 року, Закону України «Про доступ до публічної інформації» [15] від 13 січня 2011 року, розпорядження Кабінету Міністрів України «Стратегія розвитку інформаційного суспільства в Україні»[16] від 15 травня 2013 року.

Серед 3МІ вагоме значення у сфері забезпечення захисту Українських Карпат мають сучасні інтернет-медіа та відповідні групи в соціальних мережах, які дають змогу невідкладно оприлюднювати факти про екологічні правопорушення 3 метою відповідного реагування на них уповноважених суб'єктів. Так, екологічна група в соціальній мережі «Фейсбук» «Врятуй Боржаву» (англ. - Save Borzhava) (https://www.facebook.com/ save.borzhava/), яка має на меті збереження унікальної території високогір'я Карпат - полонини 
Боржава - у первозданному вигляді і недопущення будівництва вітроелектростанції (далі - ВEC) на цій полонині.

15-16 вересня 2020 року відбулось засідання Бюро Постійного комітету Бернської конвенції, де розглядалась і скарга Громадської організації «Українська природоохоронна група» щодо загрози будівництва BEC на території об'єкта Смарагдової мережі «Polonyna Borzhava» № UA0000263. За результатами засідання до Уряду України був направлений лист, у якому Комітет висловлюе свою серйозну стурбованість відсутністю прогресу і комунікації з боку представників українського Уряду і повідомляє, що ця справа у виключному порядку буде розглянута на 40-му засіданні Постійного комітету, яке відбудеться з 30 листопада до 4 грудня. На засіданні Постійний комітет має висловити свою позицію щодо скарги і розглянути питання незалежної оцінки впливу проекту ВEC на довкілля. До того ж через поточну незадовільну комунікацію Бюро вповноважує Секретаріат зв'язатись із Постійним представником України в Раді Європи для обговорення комунікаційних проблем.

Нагадаємо, що полонина Боржава є природоохоронним об'єктом міжнародного значення i входить до Смарагдової мережі Європи. Смарагдова мережа створюється за рекомендацією Постійного комітету Бернської Конвенції при Раді Європи з метою збереження біорізноманіття. Україна ратифікувала Бернську конвенцію (повна назва «Конвенція про охорону дикої флори та фауни і природних середовищ існування в Європі») у 1996 році, і тепер (за Конституцією) вона є частиною нашого законодавства, тому ми зобов'язані зберігати ці території.

Оскільки будівництво ВЕС може призвести до знищення саме тих найцінніших видів і оселищ, які охороняються у межах Бернської конвенції, Громадська організація «Українська природоохоронна група» подала скаргу до Постійного комітету, яка розглядається вже протягом двох років. У процесі розгляду Бюро Постійного комітету у листопаді 2019 року рекомендувало Уряду України призупинити реалізацію проекту ВEС, поки незалежні експерти з Комітету проведуть свою оцінку впливу на довкілля. Однак Уряд України не надіслав до Комітету жодної інформації стосовно поточної ситуації і своїх подальших дій [17];

11) неурядові організації: екологічні та правозахисні громадські об'єднання, політичні партії, благодійні організації, релігійні організації.

Зухвалі плани бізнесу щодо будівництва потужної і протяжної на 23 км хребтами BEC у високогір'ї Боржавських полонин сколихнули всю екологічну i наукову громадськість України i спричини активний спротив інституцій громадянського суспільства на Закарпатті, зокрема й Коаліційного об'єднання 34-х громадських ор- ганізацій і Форуму екологічного порятунку Закарпаття науковців, адже ці плани передбачають наймасштабніше техногенне втручання в унікальну гірську природу Закарпаття за всю його багатовікову історію. При цьому, незважаючи на серйозні загрози і ризики для природи і ландшафтів та розвитку громад краю, важливою подією, якою розпочався 2-й етап боротьби громадськості за порятунок Боржавських полонин, стало надання департаментом екології і природних ресурсів Закарпатської ОДА неадекватного стосовно проблеми капітулянтського позитивного висновку за Звітом 3 оцінки впливу на довкілля (далі - ОВД) [18].

Активну участь у порятунку полонини Боржави беруть також такі громадські організації, як Громадська природоохоронна організація «Екосфера» (м. Ужгород), Міжнародна благодійна організація «Екологія-Право-Людина» (м. Львів), Громадська природоохоронна організація «Emerald-Natura 2000 in Ukraine», Міжнародний інститут людини і глобалістики «Ноосфера» (м. Ужгород), Всеукраїнська екологічна ліга, Національна екологічна рада України, Західноукраїнське орнітологічне товариство, Всеукраїнська федерація дельтапланерного спорту України, Громадське об'єднання «Клуб піших туристів», а також релігійні організації, об'єднання та комісії: Комісія у справах екології Мукачівської греко-католицької єпархії, Комісія з екології та мігрантів Римсько-католицької конференції єпископів України, Міжрелігійний i громадянський природоохоронний Форум Східної Європи (мережеве об'єднання релігійних і громадських екологічних організацій 11 країн) - IRCEF (з головним офісом у м. Ужгороді).

Отже, неурядові організації, насамперед екологічні та правозахисні громадські об'єднання, відіграють важливу роль у забезпеченні захисту Українських Карпат;

12) юридичні та фізичні особи, які, здійснюючи практичну діяльність, зобов'язані:

- здійснювати систематичний контроль над радіаційним станом робочих місць, приміщень, територій у санітарно-захисних зонах та зонах спостережень, а також над викидами і скидами радіоактивних речовин;

- обгрунтовувати додержання норм радіаційної безпеки щодо нової (модернізованої) продукції, матеріалів і речовин, технологічних процесів і виробництв;

- своєчасно інформувати органи виконавчої влади та органи місцевого самоврядування, органи державного регулювання ядерної та радіаційної безпеки щодо виникнення аварійних ситуацій, порушень технологічних регламентів, які загрожують безпеці людини;

- забезпечувати реалізацію прав громадян та ïx об'єднань на надання інформації щодо стану довкілля. 
Фізичні особи зобов'язані не завдавати шкоди довкіллю, зокрема й екосистемам Українських Карпат, повинні здійснювати раціональне водокористування.

У цьому контексті Т. Коломоєць зазначає, що громадяни України, реалізуючи свої права, свободи й покладені на них обов'язки у сфері управління, вступають в адміністративно-правові відносини 3 державними органами і їх підрозділами й посадовими особами, а також з іншими суб'єктами адміністративного права [19, с. 48].

Отже, всі елементи національної інституційної системи адміністративно-правового регулювання захисту Українських Карпат є важливими. У їх взаємодії здійснюється ефективне адміністративноправове регулювання захисту Українських Карпат.

Висновки. На основі вищевикладеного можна зробити такі висновки. Національна інституційна система адміністративно-правового регулювання захисту Українських Карпат відіграє провідну роль у забезпеченні захисту Українських Карпат, зокрема: для збереження флори та фауни, гірських екосистем, сталого лісокористування та водокористування, охорони довкілля.

Національна інституційна система адміністративно-правовогорегулювання захисту Українських Карпат - це система вповноважених суб'єктів, що діють на основі внутрішньодержавного права України і які здійснюють адміністративно-правове забезпечення захисту Українських Карпат.

Із метою вдосконалення забезпечення сталого господарювання в лісах Українських Карпат уважаємо за доцільне створити офіційний електронний інформаційний ресурс (вебпортал) із вільним інтернет-доступом щодо поточного стану лісів в Українських Карпатах.

Існують перспективи подальших наукових досліджень у цьому напрямі щодо: порівняльно-правового аналізу захисту Карпат в Україні та в країнах ЄC; захисту фауни Українських Карпат; правового регулювання забезпечення сталого природокористування в Українських Карпатах.

Отже, у статті охарактеризовано проблематику національної інституційної системи адміністративно-правового регулювання захисту Українських Карпат.

\section{Jimepamypa}

1. Про оцінку впливу на довкілля : Закон України від 23 травня 2017 року. Відомості Верховної Ради України. 2017. № 29. Ст. 315.

2. Про заборону на проведення суцільних рубок у гірських ялицево-букових лісах Карпатського регіо- ну : Закон України в редакції від 30 жовтня 2019 р. Biдомості Верховної Ради України. 2019. № 51. Ст. 383.

3. Про Положення про Державну екологічну інспекцію України : Указ Президента України від 13.04.2011 № 454/2011. Офіиійний вісник України. 2011. № 29. Ст. 1260.

4. Про делегацію України для участі у 10-й Конференції Сторін Віденської конвенції про охорону озонового шару та 26-й Нараді Сторін Монреальського протоколу про речовини, що руйнують озоновий шар : Розпорядження Президента України від 14 листопада 2014 року № 1242/2014-рп. Офіиійний вісник Президента України. 2014. № 43. Ст. 1978.

5. Конституція України від 28 червня 1996 року. Biдомості Верховної Ради України. 1996. № 30. Ст. 141.

6. Про судоустрій і статус суддів : Закон України від 07 липня 2010 року. Відомості Верховної Ради України. 2010. № 41-42, № 43, № 44-45. Ст. 529.

7. Суд ухвалив рішення у справі щодо анулювання дозволу на виконання будівельних робіт будівництва вітрової електростанції на Полонині Боржава. URL: https://court.gov.ua/archive/873349/ (дата звернення: 14.09.2020).

8. Про Конституційний Суд України : Закон України від 16 жовтня 1996 року. Відомості Верховної Ради України. 1996. № 49. Ст. 272.

9. Про затвердження Положення про Міністерство захисту довкілля та природних ресурсів України : постанова Кабінету Міністрів України від 25 червня 2020 р. № 614. Офіиійний вісник України. 2020. № 59. Ст. 1853.

10. Про місцеве самоврядування в Україні : Закон України від 21 травня 1997 року. Відомості Верховної Ради України. 1997. № 24. Ст. 170.

11. Про службу в органах місцевого самоврядування: Закон України від 7 червня 2001 року. Відомості Верховної Ради України. 2001. № 33. Ст. 175.

12. Про друковані засоби масової інформації (пресу) в Україні : Закон України від 16 листопада 1992 року. Відомості Верховної Ради України. 1993. № 1. Ст. 1.

13. Про телекомунікації : Закон України від 18 листопада 2003 року. Відомості Верховної Ради України. 2004. № 12. Ст. 155.

14. Про основні засади розвитку інформаційного суспільства в Україні на 2007-2015 рр. : Закон України від 09 січня 2007 року. Відомості Верховної Ради. 2007. № 12. Ст. 102.

15. Про доступ до публічної інформації : Закон України від 13 січня 2011 року. Відомості Верховної Ради України. 2011. № 32. Ст. 314.

16. Стратегія розвитку інформаційного суспільства в Україні : розпорядження Кабінету Міністрів України від 15 травня 2013 р. № 386-р. Офіиійний вісник України. 2013. № 44. Ст. 1581.

17. Врятуй Боржаву @save.borzhava : Соціальний клуб. URL: https://www.facebook.com/save.borzhava/ (дата звернення: 15.09.2020).

18. Заява Форуму екологічного порятунку Закарпаття щодо Боржавських полонин від 29.03.2019 року. URL: http://life.ko.net.ua/?p=78718 (дата звернення: 15.09.2020).

19. Адміністративне право України : Підручник; за заг. ред. Т.О. Коломоєць. Київ : Істина, 2009. 480 с. 


\section{Анотація}

Дячук Н. Д. Національна інституційна система адміністративно-правового регулювання захисту Україньких Карпат. - Стаття.

Статтю присвячено проблематиці національної інституційної системи адміністративно-правового регулювання захисту Українських Карпат. Визначено окремі елементи національної інституційної системи адміністративно-правового регулювання захисту Українських Карпат.

У процесі розвитку України як демократичної i правової держави, євроінтеграції України, захисту довкілля, забезпечення сталого лісокористування та водокористування, збереження екосистеми Українських Карпат вагомого значення набуває дослідження проблематики національної інституційної системи адміністративно-правового регулювання захисту Українських Карпат.

Національна інституційна система адміністративно-правового регулювання захисту Українських Карпат відіграє провідну роль у забезпеченні захисту Українських Карпат, зокрема: для збереження флори та фауни, гірських екосистем, сталого лісового та водного користування, екологічного захисту.

Національна інституційна система адміністративно-правового регулювання захисту Українських Карпат є невід'ємним складником єдиної цілісної інституційної системи адміністративно-правового регулювання захисту Українських Карпат.

Національна інституційна система адміністративно-правового регулювання захисту Українських Карпат - це система вповноважених суб'єктів, які діють на основі внутрішньодержавного права України і які здійснюють адміністративно-правове забезпечення захисту Українських Карпат.

Важливими є всі елементи національної інституційної системи адміністративно-правового регулювання захисту Українських Карпат. У їх взаємодії здійснюється ефективне адміністративно-правове регулювання захисту Українських Карпат.

Із метою вдосконалення забезпечення сталого господарювання в лісах Українських Карпат вважаємо за доцільне створити офіційний електронний інформаційний ресурс (вебпортал) із вільним інтернет-доступом щодо поточного стану лісів в Українських Карпатах.

Ключові слова: Українські Карпати, захист Українських Карпат, інституційна система, адміністративно-правове регулювання, інституційна система адміністративно-правового регулювання, адміністративно-правове регулювання захисту Українських Карпат, національна інституційна система.

\section{Summary}

Diachuk N. D. National institutional system of administrative and legal regulation of the protection of the Ukrainian Carpathians. - Article.

The article is devoted to the problems of the national institutional system of administrative and legal regulation of the protection of the Ukrainian Carpathians. Elements of the national institutional system of administrative and legal regulation of the protection of the Ukrainian Carpathians have been determined.

In the processes of the development of Ukraine as a democratic and legal state, European integration of Ukraine, environmental protection, protection of forest and water resources of Ukraine, sustainable forest and water use, preservation of the ecosystem of the Ukrainian Carpathians, it is important to study the problematic of the national institutional system of administrative and legal regulation of the protection of the Ukrainian Carpathians.

The national institutional system of administrative and legal regulation of the protection of the Ukrainian Carpathians plays a leading role in ensuring the protection of the Ukrainian Carpathians, in particular: for the preservation of flora and fauna, mountain ecosystems, sustainable forestry and water use, environmental protection.

The national institutional system of administrative and legal regulation of the protection of the Ukrainian Carpathians is an integral part of a single integrated institutional system of administrative and legal regulation of the protection of the Ukrainian Carpathians.

The national institutional system of administrative and legal regulation of the protection of the Ukrainian Carpathians is a system of authorized entities operating on the basis of domestic law of Ukraine, which provide administrative and legal support for the protection of the Ukrainian Carpathians.

All elements of the national institutional system of administrative and legal regulation of the protection of the Ukrainian Carpathians are important, and in their interaction effective administrative and legal regulation of the protection of the Ukrainian Carpathians is carried out.

In order to improve sustainable management in the forests of the Ukrainian Carpathians, we consider it appropriate to create an official electronic information resource (Web portal) with free access to the Internet on the current state of forests in the Ukrainian Carpathians.

Key words: Ukrainian Carpathians, protection of the Ukrainian Carpathians, institutional system, administrative and legal regulation, institutional system of administrative and legal regulation, administrative and legal regulation of the protection of the Ukrainian Carpathians, national institutional system. 